\title{
THEORETICAL AND PRACTICAL ASPECTS REGARDING THE PHASE OF THE PRE-TRIAL CHAMBER PHASE IN THE CRIMINAL TRIAL
}

\author{
D. Creţu \\ C. M. Morăreanu
}

\section{Daniel Creţu}

Prosecutor's Office attached to the Costeşti Court, Costeşti, Romania

*Correspondence: Daniel Creţu, Prosecutor's Office attached to the Costeşti Court, $1{ }^{\text {st }}$ Victoriei St., Costeşti, Romania;

E-mail: danielcretu2003@yahoo.com

\section{Camelia Maria Morăreanu}

Faculty of Law and Administrative Sciences, Department of Law and Public Adminstration University of Pitesti, Pitesti, Romania

*Correspondence: Camelia Maria Morăreanu, University of Pitesti, $1^{\text {st }}$ Tg din Vale St., Piteşti

Romania;

E-mail:cameliamorareanu@yahoo.com

\section{Abstract}

The entrance into force of the new Criminal Procedure Code - namely of the Law No $135 / 2010$ - on the $1^{\text {st }}$ of February 2014, has brought in a series of modifications regarding the so-called "phases of the criminal trial". This is why, explicitly for the Romanian procedural legislation, was inserted by the legislator, before the trial itself, a pre-trial phase - hearing in the pre-trial chamber. The details of this hearing shall be analyzed below.

\section{Keywords: criminal trial, judge, trial phase, criminal investigation phase}

\section{Introduction}

The pre-trial chamber phase of the criminal trial is stated by Art 342-348 of the Code of Criminal Procedure. This institution emerged from the perspective in incrementing the celerity of the criminal trial, the new Criminal Procedure Code ${ }^{1}$ being thought from the perspective of closely stating the activity performed by the judicial authorities. By this new phase of the criminal trial was aimed the compliance with the celerity of solving criminal trials, and also a more effective use of human and financial resources.

The pre-trial chamber mainly analyzes the compliance by the criminal investigation and prosecution authorities of all procedural rights, in this procedure the judge being able to ex officio invoke exceptions, requests or exceptions may also be invoked by the other participants in the criminal trial ${ }^{2}$.

What the new Criminal Procedure Code stated, as novelty, is the impossibility of refund the case file to the prosecutor during the trial, due to the fact that the judge in the pre-trial chamber analyzes the legality of evidences and of the indictment.

This is totally different than the old regulation, because the previous Criminal Procedure $\operatorname{Code}^{3}$ stated that the indictment submitted by the prosecutor to enter directly into the criminal trial phase. Also, as a novelty element, in the pre-trial chamber emerged the principle of loyalty

\footnotetext{
${ }^{1}$ Law No 135/2010, published in the Official Gazette of Romania, Part I, No 486/15 July 2010.

${ }^{2}$ According to Art 345 Para 1 of the new Code of Criminal Procedure.

${ }^{3}$ Adopted by the Law No 29/1968, published in the Official Bulletin, No 145-146/12 November 1968, with its subsequent modifications and amendments.
} 
in managing evidences ${ }^{4}$, its violation resulting in the exclusion of the illegally obtained evidences 5 .

According to an expert analysis ${ }^{6}$, the pre-trial chamber is not an absolute novelty, the older Romanian legislation knowing the procedure called "the preparatory meeting", inserted by the Decree No 506/1953, modified by Law No 3/1956. Subsequently, by the Decree No 473/1957 this institution disappeared.

\section{The object of the pre-trial chamber}

Beyond the fact that, the criminal trial has four procedural phases, the institution is independent with attributions very well determined by the legislator by the ones stated for the judge in the pre-trial chamber ${ }^{7}$.

From the perspective of the legal text, the object of the pre-trial chamber is to verify, after the indictment, the competence and legality of notifying the court, as well as to verify the legality of the evidences and the preparation of the documents by the criminal investigation bodies $^{8}$. As an effect, this phase aims only the aspects regarding the review of legality of the documents prepared by the criminal investigation bodies, the pre-trial chamber's judge limiting his activity only to this aspect.

In this meaning, as it has been expressed, one can say that, in this new phase of the criminal trial, is performed only an a posteriorireview of the legality of the indictment and of the evidences that supports it ${ }^{9}$. From this point of view, the new regulation is different than the one stated by the old Criminal Procedure Code, when the prosecutor presented the indictment, insuring the possibility of informing ${ }^{10}$, before compiling a minute ${ }^{11}$, presentation which is no longer found in the new Criminal Procedure Code because this attribution belongs to the pre-trial chamber's judge as the notification of the indictment.

\section{The duration of the pre-trial chamber procedure}

Art 343 of the new Code of Criminal Procedure states that it is of maximum 60 days from the notification of the competent court, thus, being possible that the procedure to last lesser than the term pointed by the legislator.

From the perspective of the judicial nature of this term, regarding which the law does not make any references to a sanction for non-compliance, the practice and literature are unanimous

\footnotetext{
${ }^{4}$ According to Art 101 of the new Code of Criminal Procedure.

${ }^{5}$ According to Art 102 of the new Code of Criminal Procedure.

${ }^{6}$ C. Voicu, A. Uzlău, G. Tudor, V. Văduva, Noul Cod de procedură penală. Ghid de aplicare pentru practicieni, Hamangiu Publising House, Bucharest, 2014, p 395.

${ }^{7}$ According to Art 54 of the new Code of Criminal Procedure, the pre-trial chamber's judge is the one who, according to his competence: a) verifies the legality of the indictment submitted by the prosecutor; b) verifies the legality of the evidences and of the preparation of the documents by the criminal investigation bodies; c) solves the complaints against the solutions of not initiating the criminal investigation or not to indict; d) solves other situations express stated by the law.

${ }^{8}$ According to Art 342 of the new Code of Criminal Procedure, as it has been modified by Art 102 Point 219 of the Law No 255/2013 for the implementation of the Law No 135/2010 on the Criminal Procedure Code and for the amendment and supplementation of certain legislative acts which comprise criminal procedure provisions, published in the Official Gazette of Romania, No 515/14 August 2013.

${ }^{9}$ C. Voicu, A. Uzlău, G. Tudor, V. Văduva, op.cit., p. 396.

${ }^{10}$ According to Art 250 of the old Criminal Procedure Code, After the initiation of the criminal action, if all necessary investigation acts have been performed, the criminal investigation body calls the defendant and: a) informs him on the right to familiarize himself with the criminal investigation material, also showing him the judicial framing of the deed committed; b) offers him the possibility to immediately familiarize himself with the material. If the defendant cannot read, the criminal investigation body reads the material for him; c) asks him, after he has familiarized himself with the criminal investigation material, if he wants to make new claims or supplementary statements.

${ }^{11}$ According to Art 251 of the old Criminal Procedure Code, about complying with the provisions of Art 250, the criminal investigation body draws up an official report on the enforcement of the provisions stipulated in Art 250, also noting the statements, claims and answers of the defendant.
} 


\section{Creţu C.M. Morăreanu}

in considering that it is recommended. Thus, the thesis of overcoming it is acceptable but, because the need to respect the celerity is imperative, we consider that it can be made only for very good reasons.

\section{Preparatory measures and the trial procedure}

The new case file is randomly assigned to a panel of judges, by the ECRIS ${ }^{12}$ software, without receiving a first term. In this context, the pre-trial judge has certain attributions, specified by Art 344.

According to Para 2, the certified copy of the indictment and, where necessary, an authorized translation of it, shall be communicated to the defendant at his detention place, his residence or at an address chosen for the communication of all procedural documents, together with the specifications referring the object of the procedure in the pre-trial chamber, the right to an attorney and the deadline, within which, from the date of the communication, may submit written requests and exceptions regarding the legality of the evidences and of the documents concluded by the criminal investigation bodies. The deadline established by the Code is of 20 days. The above mentioned measure circumscribes to the warrantees of complying with the procedural rights of the person accused, here being about the right to defense, the documents communicated being analyzed by the defendant alone or together with his lawyer.

If necessary, related to the complexity and particularity of the case, the term established by the judge may exceed 20 days ${ }^{13}$.

On the other hand, if the defense is mandatory, according to Art 90 of the new Criminal Procedure Code ${ }^{14}$, the pre-trial chamber judge must take measures for appointing a public defender, in this regard submitting a request to the Bar and establishing the term in which requests and exception may be submitted regarding the legality of evidences and of the documents concluded by the criminal investigation bodies, complying with the same term of maximum 20 days.

Subsequent to these terms, all possible requests and exceptions invoked by the defendant or ex officio by the court, shall be communicated to the prosecutor who may answer them within 10 days from communication, text which does not state an obligation for the prosecutor's office to answer to all requests and exceptions. If requests or exceptions are not submitted or invoked, the pre-trial chamber's judge issues a resolution confirming the legality of the indictment, of the evidences presented during the criminal investigation and of the documents concluded in this first part of the criminal trial.

During the criminal trial procedure, a first aspect verified is that regarding the competence of the notified court, otherwise Art $50^{15}$ of the new Criminal Procedure Code becoming incident. After this moment such appreciation cannot be debated anymore, if in first instance was considered that the court notified has jurisdiction in resolving the case. Though, according to Art 421 Point 2 Let b), final row ${ }^{16}$, the jurisdiction may be re-discussed in front of the court of judicial review.

\footnotetext{
12 The ECRIS CDMS is a nationally unique software, used by the courts for the electronic management of the case files, namely for their random allocation.

${ }_{13}$ According to Art 344 Para 2 final row of the new Criminal Procedure Code.

${ }^{14}$ According to Art 90 of the new Criminal Procedure Code, judicial assistance is mandatory: a) when the suspect or defendant is minor, held in a detention or education center, when he is confined or arrested even for other offence, when he is held in a medical institution even for other offence, as well as in other situations stated by the law; b) if the judicial body considers that the suspect or defendant could not defend himself; c) for the trial of the cases for which the law states life imprisonment or imprisonment for more than 5 years.

${ }^{15}$ Declining jurisdiction.

16 According to Art 421 Point 2 Let b) final row of the new Criminal Procedure Code, "the court, resolving the appeal, shall order one of the following solutions (...) 2. Admit the appeal and (...) b) cancel the first instance court's decision and order a re-trial by the court whose decision has been canceled for the reason that the trial was held in the absence of a party who was not legally summoned or who, though legally summoned, could not attend the hearing and could not notify the court about this impossibility, invoked by that party. The re-trial by the court
} 


\section{CHAMBER PHASE IN THE CRIMINAL TRIAL}

As it has been shown by Art 345 Para 2, the pre-trial chamber's judge verifies if the indictment has certain irregularities which should be remedied, analyzing the criminal investigation documentation and the evidences only regarding to their legality and in accordance with Art 102. If irregularities are found within the indictment or violations of the process of collecting the evidences, the judge shall apply Art 280-282 relative to Art 102 Para 3. The nullity of the document ordering to collect evidence or authorizing certain evidence determines the rejection of that evidence.

Regarding the nullity of procedural documents, as it has been mentioned by the Explanatory Memorandum to the draft of the New Criminal Procedure Code, the modifications inserted by the actual code systematizes their specific issues, the provision of the effects of nullity of these procedural documents, as well as that of the subsequent documents, representing a novelty ${ }^{17}$.

If the pre-trial chamber's judge applies Art 280-282, he shall communicate the resolution to the prosecutor's office, after that the prosecutor, within 5 days from the notification, must correct the irregularities in the indictment and communicate to the judge if he chooses to support it or not, otherwise requesting the case file to be refunded. If the prosecutor's office supports the indictment and if all the evidences have not been excluded from the criminal investigation the judge shall order the beginning of the trial.

\section{The solutions ordered and the ways of appeal}

The solutions to be ordered are stated by Art 347 Para 1-7. After the resolution ordering the initiation of the trial, the criminal case file receives a term for the first hearing, using the ECRIS software.

The pre-trial chamber's judge may order the refund of the case file to the prosecutor's office, according to any of the letters stated by Art 346 Para 3, as he gives the solution for jurisdiction issues mentioned in the case file. Art 346 Para 7 of the new Criminal Procedure Code states that the pre-trial chamber's judge who ordered the initiation of the trial acts in the pending case file. Initially, the legislator's idea was that of the existence of an incompatibility between the two mentioned attributions, for the current version of the new Criminal Procedure Code to remove this incompatibility, one of the reasons being that of limited human resources.

The appeal is dominated by short terms, supporting the celerity in resolving the criminal trial. It shall be submitted within 3 days, both for the prosecutor, as well as for the defendant, and shall begin from the communication of the decision. Thus, no other party in criminal trial, apart from the prosecutor or defendant, may initiate it. The appeal thus submitted to the court in which the pre-trial chamber's judge who ordered the attacked resolution is member, shall be notified for competent resolution to the pre-trial chamber's judge member of the hierarchic court. In the absence of any provision in this regard, the panel of judges of the hierarchic court shall not be collegial, but shall consist of only one judge. If the High Court of Cassation and Justice is notified, the appeal shall be resolved by the competent panel of judges, according to the law. Since it is a mean of attack, the appeal may be withdrawn, according to Art 415. Likewise, according to Art 416, the initiation of the appeal suspends the normal flow of the criminal trial, because until its resolution the judicial investigation cannot be initiated. Also because it is a mean of attack, according to Art 418, the principle of non reformatio in pejus is incident, of nonaggravating the situation in his own appeal.

The resolution of the appeal has the same phases as its hearing on the merits of the case, the trial overlapping the same procedural provisions. The pre-trial chamber's judge shall order,

whose decision has been canceled shall be ordered also in the presence of one of the cases for absolute nullity, except the case of incompetence, when shall be ordered the re-trial by the competent court".

17 Explanatory Memorandum to the draft of the New Criminal Procedure Code available on www.just.ro p 15. 


\section{Creţu C.M. Morăreanu}

by decision, one of the solutions stated by Art $425^{1}$ Para 7 of the new Criminal Procedure Code, inserted by the G.E.O No $3 / 2014^{18}$, which is a final and irrevocable decision ${ }^{19}$.

\section{Preventive measures during the pre-trial chamber phase}

These can also be adopted during the pre-trial chamber procedure. According to Art 348 Para 1, the pre-trial chamber's judge orders, by request or ex officio, regarding the establishment, maintenance, replacement, revocation or termination ipso jure of the preventive measures.

Examining the law leads to the conclusion that all the preventive measures stated in Art 202 Para 4 Let b)-e) of the new Criminal Procedure Code may be ordered also by the pre-trial chamber's judge as also stated by Art 203 Para 2-3. The judicial review and the judicial review on bail, the house arrest and the remand in custody may be ordered by the pre-trial chamber's judge, as an effect of the prosecutor's proposal or ex officio.

Analyzing the preventive measures during the pre-trial chamber phase cannot be performed without mentioning Art 207, referring to the verification of the preventive measures in the pre-trial chamber both for the assignation of the defendant, but also if the preventive measure is ordered, for the first time, by the pre-trial chamber's judge.

For the first situation, the judge must ex officio verify the legality and solidity of the preventive measure, the term recommended by the legislator being of 3 days starting from the registration of the case file, but before the expiration of the period for which the preventive measure has been ordered ${ }^{20}$.

In both cases, of maintaining or revoking the preventive measure, the pre-trial chamber's judge shall deliver a motivated resolution, in the council room, which may be appealed within 48 hours from deliverance or notification.

The legality and solidity of the house arrest or the remand in custody measure are periodically reviewed, ex officio, every 30 days, unlike the trial phase in which the term is double. If this review has not been performed, then the preventive measure shall terminate ipso jure, the pre-trial chamber's judge applying Art $241^{21}$.

\section{Bibliography:}

- C. Voicu, A. Uzlău, G. Tudor, V. Văduva, Noul Cod de procedurăpenală. Ghid de aplicare pentru practicieni, Hamangiu Publ.-house, Bucharest, 2014;

- Government Emergency Ordinance No 3/5 February 2014 for the implementation of the Law No 135/2010 on the new Criminal Procedure Code and ofcertain legislative acts;

- Law No 255/2013 for the implementation of the Law No 135/2010 on the Criminal Procedure Code and for the amendment and supplementation of certain legislative;

- Law No 135/1 July 2010 on the new Criminal Procedure Code;

- Law No 29/1968 on the old Criminal Procedure Code.

\footnotetext{
${ }^{18}$ G.E.O No 3/5 February 2014 for the implementation of the Law No 135/2010 on the new Criminal Procedure Code and of certain legislative acts, published in the Official Gazette of Romania, No 98/7 February 2014.

${ }^{19}$ The pre-trial chamber's judge of the hierarchic court shall deliver one of the following solutions: 1 . Reject the appeal, maintaining the decision appealed: a) when the appeal is tardy or inadmissible; b) when the appeal is indefeasible; 2. Admit the appeal and: a) the cancelation of the decision and solve the case file; b) the cancelation of the appealed decision and order a re-trial of the case file by the judge or panel of judges who or which resolved it, when it is established that the provisions on summoning have not been observed.

${ }^{20}$ According to Art 207 Para 2 of the new Criminal Procedure Code.

${ }^{21}$ According to Art 241 Para 3 of the new Criminal Procedure Code, the pre-trial chamber's judge shall order, by motivated resolution, regarding the termination ipso jure of the preventive measure also in the absence of the defendant, but in his lawyer's and the prosecutor'smandatory presence.
} 